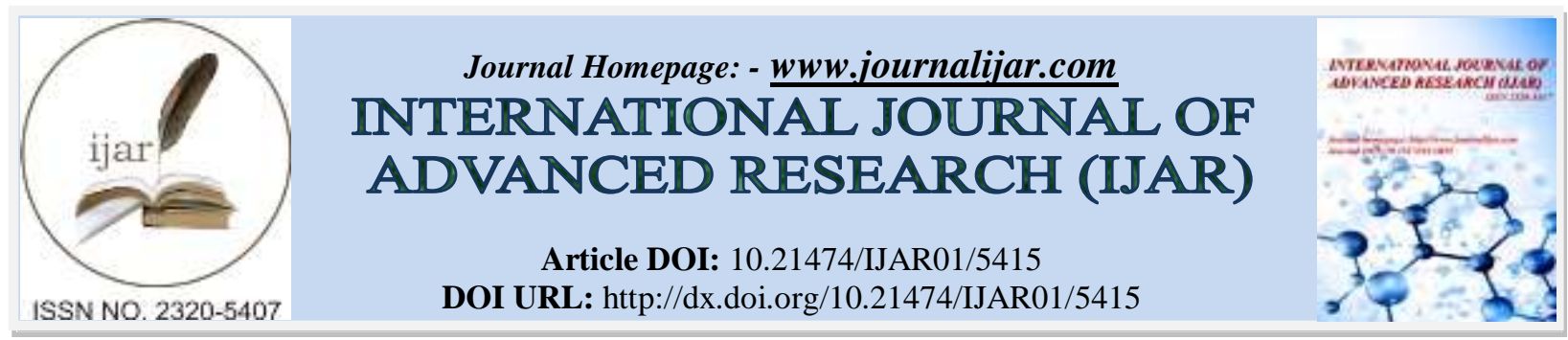

RESEARCH ARTICLE

\title{
ESTIMATION OF SEDIMENT YIELD OF SONAI RIVER USING SEDIMENT RATING CURVE AND GEOGRAPHIC INFORMATION SYSTEM.
}

Sadria Begam $^{1}$ and A. K. Barbhuiya ${ }^{2}$.

1. Department of Civil Engineering, National Institute Of Technology Agartala, India.

2. Department of Civil Engineering, National Institute of Technology Silchar, India.

\section{Manuscript Info}

Manuscript History

Received: 13 July 2017

Final Accepted: 15 August 2017

Published: September 2017

Key words:-

GIS, Sediment rating curve, SCS-CN, Sediment yield.

\begin{abstract}
The aim of this research is to estimate sediment yield in Sonai River by sediment rating curve and an empirical formula. The study has been carried out to determine and impose sediment yield in the Sonai River in Assam to be able to estimate average annual sedimentation during the period of 2003 to 2005. Measurement data of daily suspended sediment concentration and water discharge is obtainable during 3-year period (2000-2002) in the Tula gram station of Sonai River. Data were collected from Central Water Resource Commission, Shillong. These data sets, such as daily mean water discharges and daily mean suspended sediment discharges were used to develop sediment rating curves for small periods of time. Once the rating curves for water discharge and sediment concentration Were defined, they were used with daily water discharge data to predict monthly and annual sediment yield of Sonai river during 2003-2005 and by this rating curve calculated sediment yield is 26.08 ton/ha/year where observed sediment yield is 25.05 ton/ha/year which is near to the calculated value. For the judgments of accuracy of the result another method for determined sediment yield is empirical method (Dendy Bolton formula, 1976). Runoff and area of watersheds is used in this formula of sediment yield. Runoff is calculated from SCS-CN curve number method and Area of watershed is developed by ARC GIS .By this empirical method the average annual sediment yield during 2003 to 2005 is 31.07 ton/ha/year. So from these two processes sediment yield determined by sediment rating curve is more accurate than the empirical method
\end{abstract}

Copy Right, IJAR, 2017,. All rights reserved.

\section{Introduction:-}

Sediment yield estimation in watershed areas are very important for designing control canals against flood, estimation of sedimentation in reservoir and control navigation canals. Actual sediment load of a river basin in a given time requires continuous records of flow discharge and suspended sediment concentration. Then the most common means of load estimation is to perform linear regression analysis on logarithms of the sediment load and discharge data, called conventional sediment rating curve (CSRC). This method is long-established method (Miller 1951), but still in use.

Corresponding Author:- Sadria begam.

Address:- Department of Civil Engineering, National Institute Of Technology Agartala, India. 
Sediment-discharge measurements usually are available on a discrete or periodic basis. However, estimates of sediment yield often are needed for unmeasured periods, such as when daily or annual sediment-discharge values are sought, or when estimates of unmeasured or hypothetical sediment discharge required. The purposes of this contribution are to present some limitations and potential pitfalls associated with obtaining and using the requisite data and equations to estimate sediment discharges and to provide guidance for selecting appropriate estimating equations.

To compare the sediment yield by sediment rating curve another method for determining sediment yield is the Dendy Bolton formula (journal of Environmental Hydrology 2009) to determine sediment yield. The sediment yield calculated by the USLE includes only one type of sediment yield such as sheet and rill Erosion. Dendy Bolton formula, (1976) is used to determine sediment yield of all types of erosion such as sheet and rill Erosion, gully Erosion, channel Bed and bank erosion and mass movement. Area of watershed by Arc GIS and Runoff of the basin is used to determine sediment yield in the Dendy Bolton method

The analysis is based on field survey data of daily River flow discharge and sediment concentration data collected in 2000 to 2002. These data are used to develop relationship between flow discharge and sediment concentration by regression analysis and sediment rating curve.

II. Study area Description and available data

The study area is a watershed of Sonai River basin located in the Assam, India. It is the right bank tributary of Barak river .The river Sonai joining from south bank of the Barak river. The watershed area of Sonai River is $722.796 \mathrm{~km}^{2}$ and situated between $24^{\circ} 26^{\circ} 29.62^{\circ} \mathrm{N}$ latitude and $92^{\circ} 55^{\circ} 26.22^{\circ} \mathrm{E}$ longitudes . The river mainly originates from the Lusai hills of Mizoram and after a tortuous northerly course of about $96 \mathrm{~km}$ through Mizoram and the Cachar districts of Assam, join the Barak when Barak reach from Lakhipur to Indo-Bangladesh Border. The river Barak with its tributaries is the second largest river system of the North -Eastern region and is a part of the GangaBrahmaputra- Meghna system. The river Sonai is situated on the route of the south-west monsoon. During the monsoon period, intensity of rainfall can be as $250 \mathrm{~mm}$ per day and most of the heavy rainfall occurs in the short span of the month's viz. June, July and August.

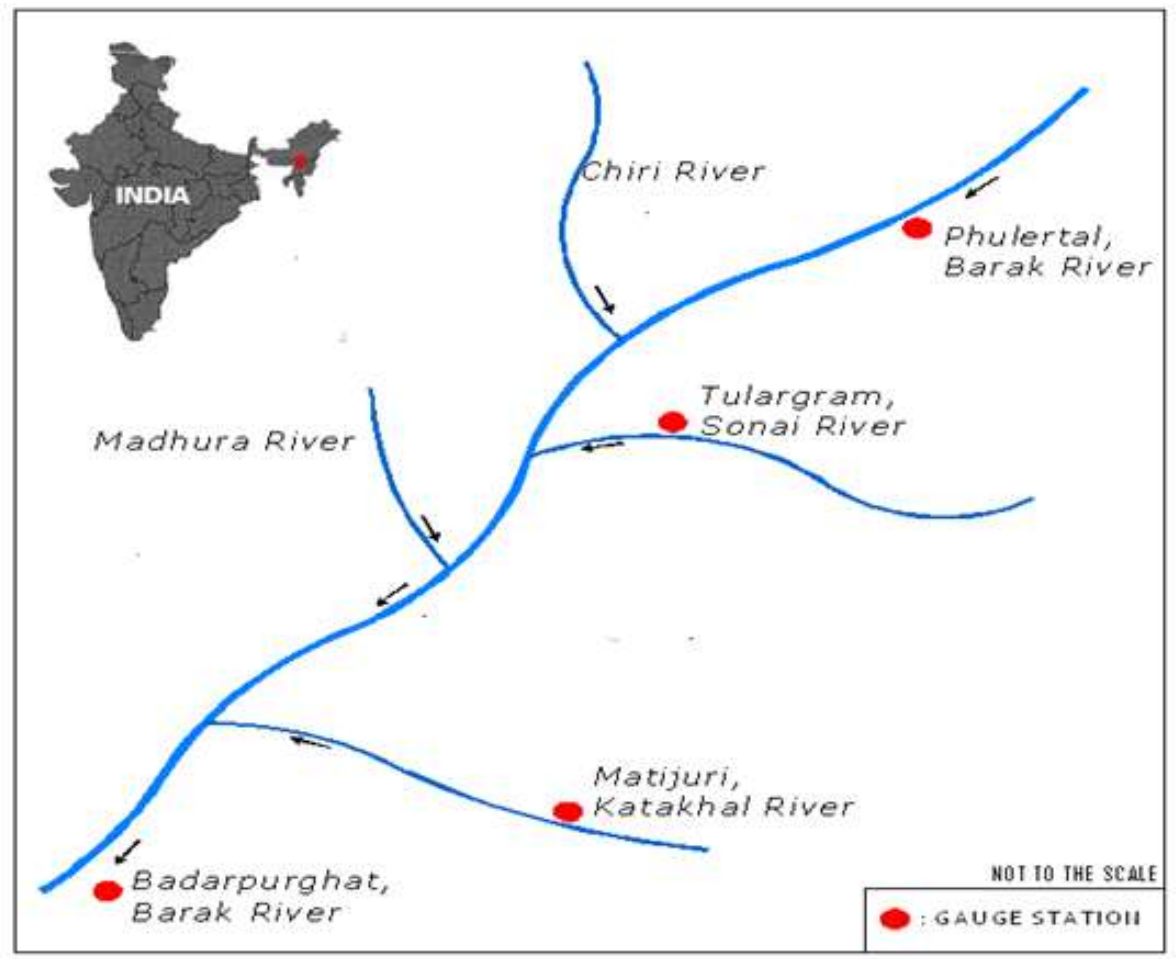

Fig1: Location of Sonai River. 



Fig 2: Area of River

Fig 3: Flow direction of River

Fig 4: Flow accumulation of River

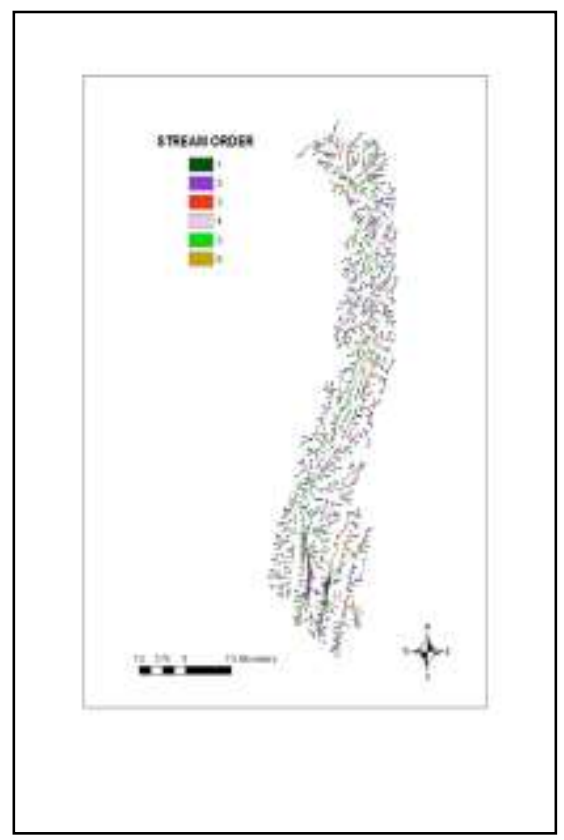

Fig 5: Stream Order of the River

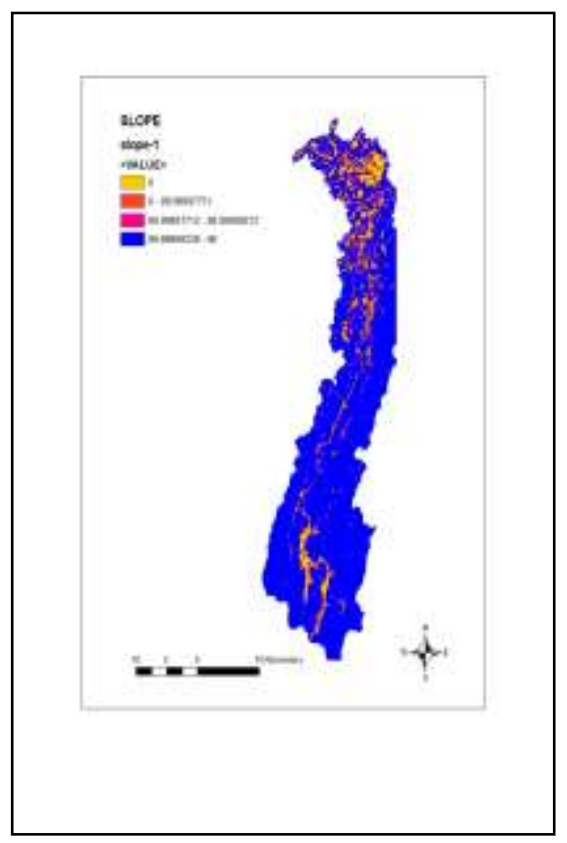

Fig 6: Slope map of the River

The dataset used in this study includes 1103 daily discharge and sediment concentration measurements conducted by

Central Water Resource Commission, Shillong from 2000 to 2005, Rainfall data conducted by Indian Meteorological Department, Shillong from 2002 to 2005 and soil type map of Cachar district of Assam conducted by NESAC, Shillong. 


\section{Result and discussion:-}

In this study a sediment rating curve was developed on the basis of field measurement (1096 sample points) for Sonai river for during the period of 2000-2002. Mathematical functions of best fitting curve is mostly used for quadratic and cubic polynomial i.e. exponential and potential type equation. To illustrate this, Fig (7) shows this relationship for the gauging station Sonai river with a tributary basin of $722.796 \mathrm{~km}^{2}$ where measurements of water discharge and suspended sediment concentration, for the period 2000-2002, are available .From this relationship with available 1096 samples of daily water discharge and sediment concentration data during the period of 2000 t0 2002 the sediment yield of 2003-2005 were determined. Regression models were developed between SSC and stream flow.

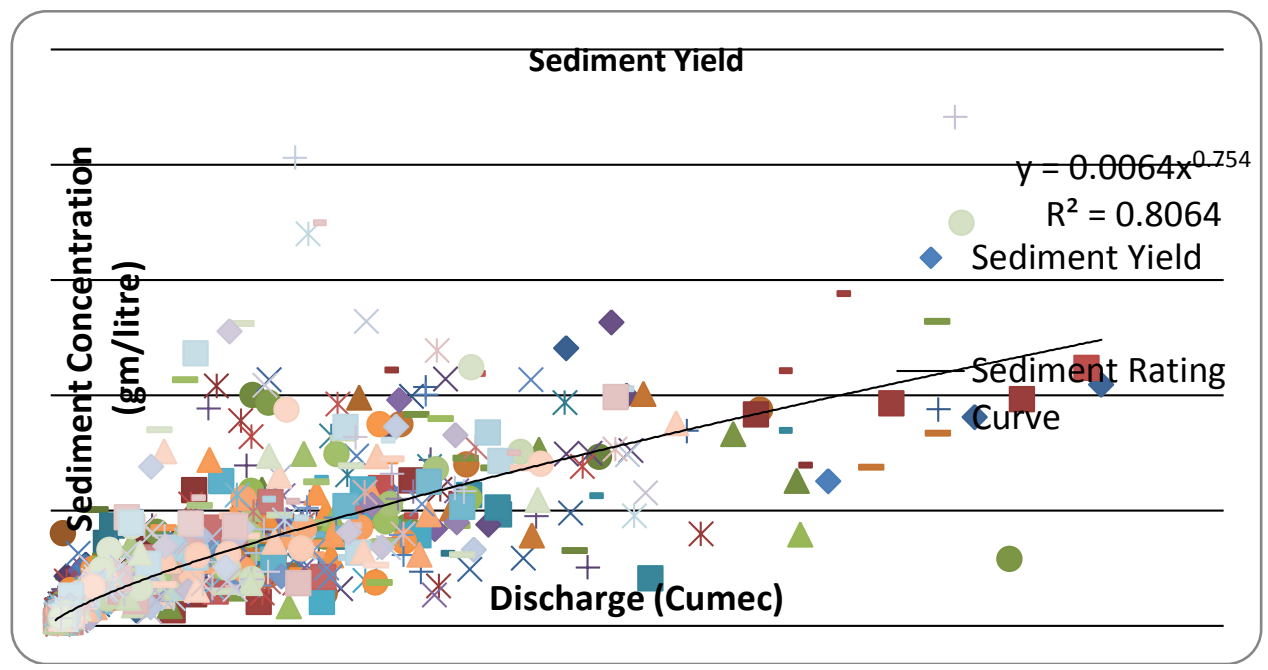

Fig 7: Sediment rating curve between flow discharge and Sediment concentration

Regression models were developed between suspended sediment concentration (SSC) and stream flow. The relation between SSC and stream flow was significant and positive $\left(r^{2}=0.806\right)$ with variation in the data. By the regression analysis and using equation the empirical driven coefficients are $\mathrm{a}=0.006$ and $\mathrm{b}=0.754$ and also by plotting the curve between flow discharge and sediment concentration, sediment rating curve equations (Fig-7) for the dataset is

$$
\mathrm{Qs}=0.006 \mathrm{Q}_{\mathrm{w}}^{0.754}
$$

So, the regression coefficients $\mathrm{a}$ and $\mathrm{b}$ are $\mathrm{a}=0.006$ and $\mathrm{b}=0.754$ respectively. These two regression coefficients $\mathrm{a}$ and $\mathrm{b}$ with the relationship of rating curve and given discharge data are used for the estimation of sediment yield from 2003 to 2005 (36 months).Daily discharge was summed to give an monthly discharge .Monthly discharge was summed to give an annual discharge, and then an annual discharge was inserted to equation (1) give an annual sediment yield.

Monthly Sediment yield graph during 2003-2005 by using sediment rating curve are as follows: 


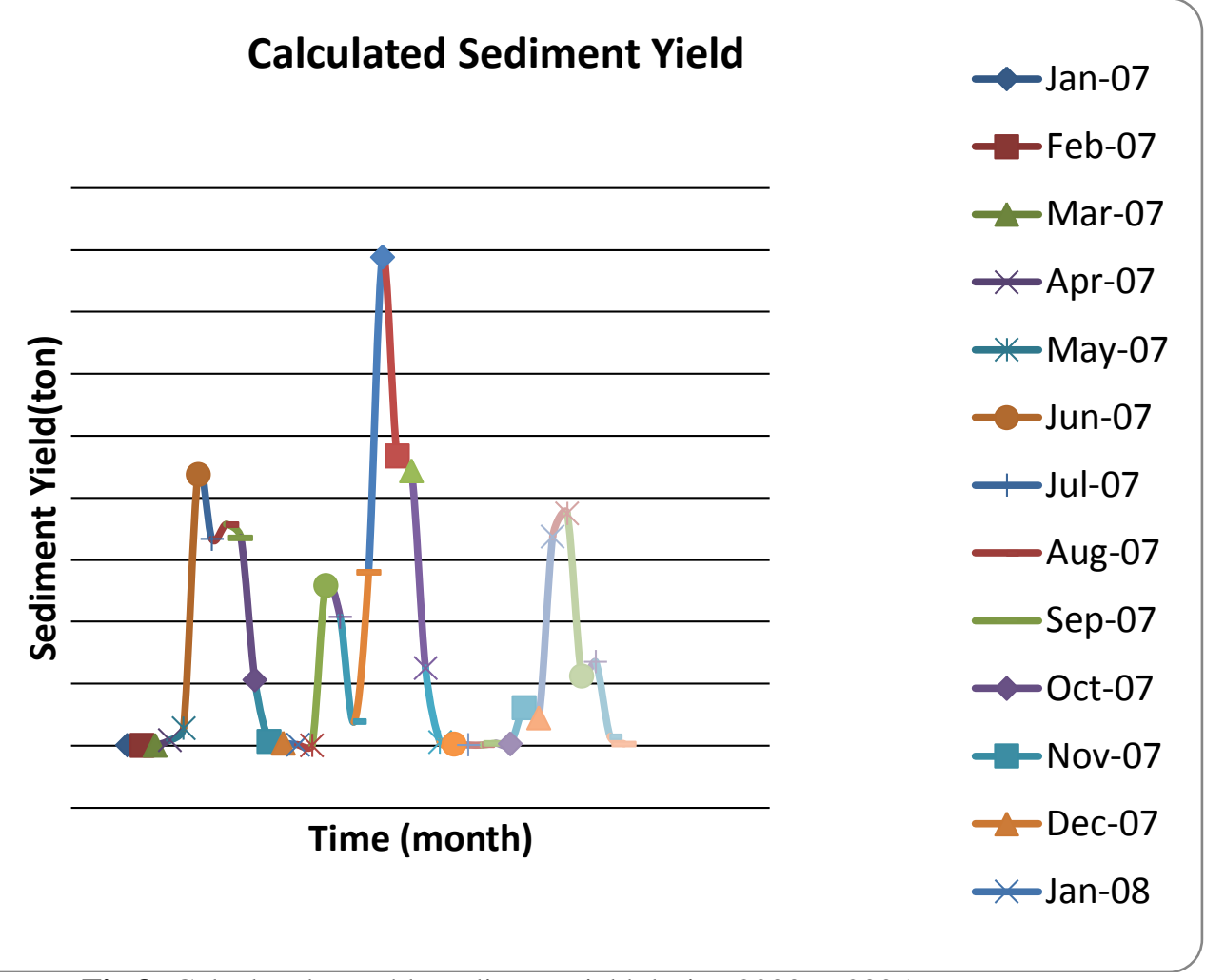

Fig 8: Calculated monthly sediment yield during 2003 to 2005

Table 1:- Calculated Monthly Sediment Yield

\begin{tabular}{|l|l|l|l|}
\hline \multirow{2}{*}{ Month } & \multicolumn{2}{|c|}{ Yearly Sediment Yield (ton) } \\
\cline { 2 - 4 } & 2003 & 2004 & 2005 \\
\hline January & 881.435 & 1668.237 & 1064.065 \\
\hline February & 543.284 & 732.280 & 1021.034 \\
\hline March & 604.707 & 258153.234 & 3765.788 \\
\hline April & 8614.488 & 207531.861 & 2974.814 \\
\hline May & 28422.382 & 38359.064 & 61464.651 \\
\hline June & 437382.496 & 280088.868 & 44880.591 \\
\hline July & 333153.936 & 788255.158 & 337680.604 \\
\hline August & 357015.363 & 466918.570 & 374745.212 \\
\hline September & 335631.958 & 443534.534 & 112520.592 \\
\hline October & 106141.883 & 125263.294 & 135350.407 \\
\hline November & 6418.310 & 6153.113 & 14809.682 \\
\hline December & 4070.924 & 2278.005 & 2912.974 \\
\hline Total & 1718238.753 & 2808865.300 & 904526.389 \\
\hline
\end{tabular}

Monthly sediment discharge was summed to give an annual discharge, and then an annual discharge was inserted to equation (1) gives a calculated average annual sediment yield of 26.08 ton /ha /year where observed sediment yield is $25.06 \mathrm{ton} / \mathrm{ha} /$ year.

The comparison of graph between observed sediment yield and calculated sediment yield are given below .There is no much difference between the sediment yields so the sediment rating curve is more accurate. 


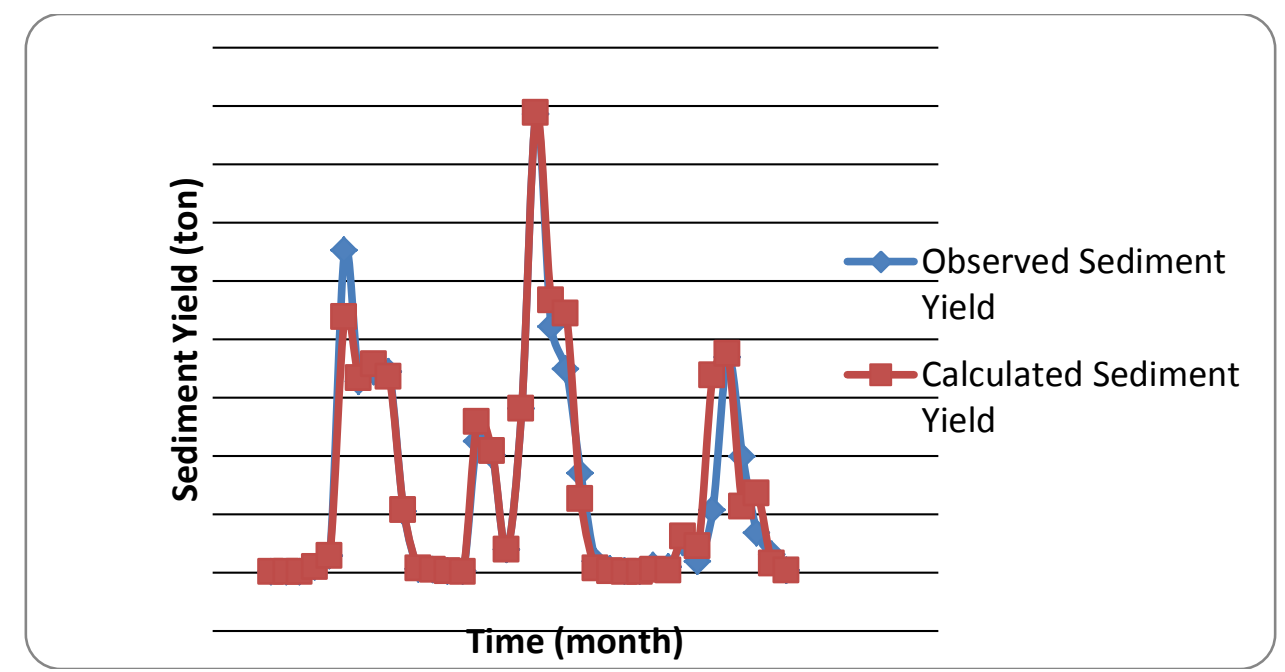

Fig (9): Observed and Calculated sediment yield graph

As presented above application of curve number and runoff equation requires $\mathrm{S}$ which is calculated from $\mathrm{CN}$.The conceptualization of $\mathrm{CN}$ as a measure of watershed response hydrology based on soils, cover and land use was an additional major step.

According to Soil data collected from NESAC the soil of Sonai River is loamy and the soil of Sonai River is HSG B type of soil and for B type of soil has curve number of 48. so the curve number of Soil of Sonai River is 48.Annual average Potential maximum precipitation by using the equation 4.3 is $S=275.17 \mathrm{~mm}$.Annual average precipitation during the period 2003-2005 is $\mathrm{P}=2611.9 \mathrm{~mm}$ or 102.83 inch Annual runoff during the period 2003-2005 by using the equation 4.1 is $\mathrm{Q}=2281.17 \mathrm{~mm}$ or 89.81 inch and average annual sediment yield by using area of Sonai River (279 mile ${ }^{2}$ or $722.796 \mathrm{~km}^{2}$ ) determined by arc GIS and annual runoff of 89.81 inch is 8046.78 ton/acre/year or $31.06 \mathrm{ton} / \mathrm{ha} / \mathrm{year}$.

\section{Conclusion:-}

The spatial distribution of the average annual sediment yield in the Sonai River Watershed, estimated using the Rating Curve or regression analysis and Empirical method shows that the average annual sediment yield ranges up to a maximum value of $26.08 \mathrm{ton} / \mathrm{ha} /$ year and $31.06 \mathrm{ton} / \mathrm{ha} /$ year respectively .The average annual observed sediment yield is 25.05 ton/ha/year .Results obtained applying two different techniques shows that determination of Sediment yield by sediment Rating Curve is more accurate. In this model from the monthly calculated sediment yield graph it is clear that sediment yield mostly occurs during the month of Jun, July and August. Estimated values falls under the severe soil erosion class according to the Table 7.1 as suggested by Singh et al (1992).It appears that sediment rating curves can be used to generate reasonably accurate suspended sediment flux estimates for large, medium and relatively small rivers. As such, for these longer time-frames, sediment rating curves represent a markedly cheaper alternative than such methods as automatic samplers. From this study it is also clear that sediment yield can also be developed by rainfall and area of watershed by empirical method but if data are available than sediment can also be calculated most accurately by sediment rating curve. In this study sediment yield ranges from 20 to 40 , so very high class of soil erosion is occurs in Sonai River.

\section{REFERENCES:-}

1. Asselman,N.E.M."Fitting and interpolation of sediment rating curves". J.Hydrology, 343, 224-248. 2000

2. Angelis I ,Metallions A , Hrissanthou V "Regression analysis between sediment transport rates and stream discharge for the Nestos River" Global NEST Journal, Volume 14, No3, pp 362-370. 2012

3. ArabkhedriMahmood,. Lai F. S, Ibrahim Noor-Akma andMohamadMohamad-RoslanKasim "Effect of aduptive cluster sampling design in the accuracy of sediment rating curve estimation". J. Hydrol. Eng.15:142151.2010.

4. Ashaq Hussain Sheikh, SarveshPalria and Akhtar Alam "Integration of GIS and Universal Soil loss equation for soil loss estimation in Himalayan watershed”. Recent Research in science and Technology, 3(3): 51.2011. 
5. Banasik Kazimierz "Empirical determination of runoff curve number for a small agricultural watershed in Poland" Warsaw University of Life Sciences -SGGW, Department of Water Engineering, Sedimentation Laboratory, Warsaw - Poland. 2010.

6. Chow, V. T., ed. "Handbook of applied hydrology".McGraw-Hill, New York, 13 -17. 1964.

7. Christensen, V.G., Jian, Xiaodong, Ziegler, A.C. "Regression analysis and real -time water quality monitoring to estimate constituent concentrations, loads, and yields in the Little Arkansas River".South-Central Kansas, 1995-99: U.S. Geological survey Water-Resources Investigations Report 00-4126, 36 p. 2000.

8. Collins, D.L) "Computation of records of stream flow at control structures".U.S. Geological Survey WaterResources Investigations Report 77-8, 57 p. . 1977

9. Cordova J.R, Gonzalez M. "Sediment yield estimation in small watersheds based on stream flow and suspended sediment discharge measurements"Soil Technology 11, 57-65. 1997

10. Crawford, C. G. "Estimation of suspended-sediment Rating curves and mean Suspended-sediment loads". $J$. Hydrology. 129:331-348. 1991

11. Denve. Lu, H., Moran, C. J. and Prosser, I. P. "Modelling sediment delivery ratio over the Murray Darling Basin." Environ Modell.Software.2006

12. Ferguson, R. "River loads underestimated by rating curves."Water Resource Res, 2(1), 74-76,1986.

13. Horowitz, A. J., "An evaluation of sediment rating curve for estimating suspended sediment concentration for subsequent flux calculations". Hydrology .proc, 17, 3387-3409. 2003.

14. Jansson, M. B. "Estimating a sediment rating curve of the Reventazón river at Palomo using logged mean loads within discharge Classes." J. Hydrology, 183(3-4)227-241,1996.

15. Miller, C. R.). "Analysis of flow-duration, sediment-rating curve Method of computing sediment yield", U.S. Bureau of reclamation, 1951.

16. Roman David C, Vogel Richard M,. Schwarz "Regional regression models of watershed suspended sediment discharge for the eastern united states" Journal of Hydrology 472-473 (2012) 53-62. 2012

17. Sadeghi, S. H. R., et al. "Development, evaluation and interpretation of sediment rating curves for a Japanese Walling small mountainous" 2008.

18. D. E. "Assessing the accuracy of suspended sediment rating curves for a small basin." Water Resource. Res., 13, 531-538.1977.

19. Richard H.Hawkins, Timothy J Ward, Donald E Woodward, Joseph A Van Mullem "Curve number hydrology task Committee". Environmental and water resource Institute (US) 2009. 